\title{
そで壁を内蔵する鉄筋コンクリート造架構の構造性能に関する研究 STRUCTURAL PERFORMANCE OF REINFORCED CONCRETE FRAME WITH NON-STRUCTURAL REINFORCED CONCRETE WALLS (SIDEWALLS)
}

\author{
杉山智昭*, 松崎育弘**, 中野克彦*** \\ Tomoaki SUGIYAMA; Yasuhiro MATSUZAKI and Katsuhiko NAKANO
}

\begin{abstract}
The aim of this paper is to estimate the structural performance (stiffness, capacity, failure modes and ductility) of the Reinforced Concrete $(\mathrm{RC})$ frame with cast-in-place non-structural $\mathrm{RC}$ walls (sidewalls).

This paper mainly describes the structural performance of the RC frame under the situation of which the column and the sidewall slide off vertically. A shear-loading test and a finite element analysis (2-D non-linear analysis) were conducted using one-story RC frame with non-structural walls (sidewalls). From the test and the analysis, the shear resistant mechanism of the RC frames was clarified. Further, the load-deformation relationship of the RC frame can be predicted by a evaluation method verified with the shear resistant mechanisms.
\end{abstract}

Keywords : Reinforced Concrete, Non-structural wall, Frame, Experiment, Finite element method 鉄筋コンクリート造, 非構造壁, 架構, 実験, 有限要素法解析

\section{1. はじめに}

柱および梁で構成される架構型の鉄筋コンクリート造建物では, 様々な用途から，腰壁，たれ壁，そで壁および方立て壁といった非 構造壁 ( 2 次壁)が混在して構面内に設けられる。これら非構造壁は, 柱・梁の構造部材と同時に施工されるのが一般的なため, 構造体と の間に応力伝達が発生し, 地震時の建物挙動に多大な影響を与える ことになる。この影響は, 構造体(柱)に取り付く壁板の形状から(1) 腰壁・たれ壁的な挙動，(2)そで壁的な挙動，(3)方立て壁的な挙動に 分けられる。これらの挙動は, 地震が発生するごとに, (1)に関して は，変形が拘束された(短柱化による)柱のせん断破壊や，(2)に関し ては, 剛性が高くなって忘力が集中することで生じた柱のせん断破 壊として報告されており ${ }^{1)}$, 非構造壁が架構の構造性能に悪影響を 与えるとみなされる傾向が強くなっている。しかしながら, 非構造 壁が構造部材よりも先に破壊することで架構の損傷が軽微になった 被害 ${ }^{2)}$ 同時に報告されており;一概に，非構造壁の存在は，耐 震上不利であると判断することもなさそうである。この様に非構造 壁が存在する架構の挙動は複雑になるため，建築物の構造規定 ${ }^{3) p ~}$ 既存鉄筋コンクリート造建築物の耐震診断基準 4) において, 非構 造壁の取り扱いは未だ不明確であり, 適切な評価方法が求められる。 一方, 非構造壁と構造部材の応力伝達をディテールの面から回避 する事を目的とした，『構造用スリット』と呼ばれる目地について
使用が推奨されている。しかし，この方法は，非構造壁を構造体か ら切り離すことで, 結果的に架構全体の剛性と耐力を共に低下させ る恐れも併せ持っている。また，スリットの使用には, 目地部分の 防水と耐火の問題, 配筋やコンクリート打設など施工上の問題も指 摘されている。更に，いわゆる、部分スリット』は，非構造壁の存 在による力学的影響は無視し得ないことが示されておりら)，構造用 スリットを用いる場合にも適切な評価および使用方法が必要となる。

筆者らは，非構造壁と構造部材の破壊を制御した，架構の構造性 能評価法の提案を目的として研究を進めている。文献 6) では，非 構造壁が取り付く柱の特性が卓越する架構に対して実験を行い，柱 のせん断補強量が十分な場合には, 非構造壁を構造部材よりも先行 して破壊させるなど, 柱と壁板の応力伝達を許容した設計法も選択 可能であることを示した。そして，たれ壁・腰壁的挙動となる非構 造壁が存在する架構について，柱部材と壁板のせん断力に対する抵 抗機構をモデル化することで，構造性能評価法を提案している。

本論文では，そで壁的举動となる非構造壁を内蔵する架構につい て構造性能評価法を提案することを目的としている。そで壁が接合 する柱に関しては, 構造性能評価法について研究が進められつつあ る(刚え(47)，8)なと。しかし，これら研究は，柱とそで壁が一体として 举動する状況について対象としており，多くの実験研究で報告され ている，柱部材とそで壁の接合面近傍においてひび割れが著しくな
* 東京理科大学工学部建築学科 助手 ·博士 (工学)

** 東京理科大学工学部建築学科 教授. 工博

*** 新潟工科大学工学部建築学科 助教授 $\cdot$ 博士 (工学)
Research Assoc., Dept. of Architecture, Faculty of Eng., Tokyo Univ. of Science, Dr. Eng.

Prof., Dept. of Architecture, Faculty of Eng., Tokyo Univ. of Science, Dr. Eng.

Assoc. Prof., Dept. of Architecture, Faculty of Eng., Niigata Institute of Technology, Dr. Eng. 
り，柱とそで壁が接合面でずれる(すべる，スリップする)挙動に関 してなど，不明な点がいまだ多い。ここでは，これら破壊モードを 明確に区分した架構の復元力包絡線(荷重一変形関係)の評価方法を, 実験および有限要素法数值解析を用いて，柱と壁板のせん断力に対 する抵抗機構を適切にモデル化して提案する。

\section{2. 構造性能評価のための実験}

構造性能評価に必要な知見を得るために実験を行った。文献 6 ) では，柱の片側にそで壁が接合する架構の実験 (No.1-2：図 1 〜図 4 および表 1 〜表 2 参照)を行い，柱とそで壁が接合部近傍で鉛直 方向にすべる性状について示した。ここでは，より多くの要因に対 して性状を知るため, 試験体(No.3-2)を追加して実験を行った。

\section{1 実験概要}

表 1 に試験体要因一覧，図 1 に試験体形状および配筋図を示す。 試験体は 1 層で柱が 3 本存在する架構であり，大きさは実大の約 1/3である。架構内の壁板は柱と梁に剛接合させている。

柱の芯々寸法は $(l) 2000 \mathrm{~mm}$, 柱の脚部からせん断力加力点までの 距離は $1400 \mathrm{~mm}$ とした。また，柱断面 $\left(B_{C} \times D_{C}\right)$ は $240 \times 240 \mathrm{~mm}$ ， ス タブ梁断面 $\left(B_{B} \times D_{B}\right)$ は $800 \times 600 \mathrm{~mm}$ と岡強で，柱の特性が卓越する 架構として設定している。柱主筋は 12-D13(SD345)，壁せん断補強 筋は綎，横ともにD4@105 とし，壁筋は，長さ $210 \mathrm{~mm}$ で柱と梁に

表 1 試験体要因一覧

\begin{tabular}{|c|c|c|c|c|c|c|c|c|}
\hline \multirow[b]{2}{*}{ No. } & \multirow[b]{2}{*}{ 試験体名 } & \multicolumn{3}{|c|}{ 柱部 } & \multicolumn{3}{|c|}{ 壁部 } & \multirow{2}{*}{\begin{tabular}{|l} 
コンクリ \\
一ト圧縮 \\
強度 $\sigma{ }^{8}$ \\
{$\left[\mathrm{~N} / \mathrm{mm}^{2}\right]^{8}$}
\end{tabular}} \\
\hline & & $\begin{array}{l}{\left[\begin{array}{ll}* \\
B\end{array} \text { 面 }\right.} \\
{[\mathrm{mm}]} \\
\end{array}$ & \begin{tabular}{|c|} 
主笳 \\
D13 \\
[SD345]
\end{tabular} & $\begin{array}{l}\text { せん断 } \\
\text { 補強筋 } \\
\text { [SD295] }\end{array}$ & \begin{tabular}{|c} 
壁厚 \\
$t$ \\
[mm]
\end{tabular} & $\begin{array}{l}\text { そで壁 } \\
\text { 長さ } \\
{[\mathrm{mm}]}\end{array}$ & \begin{tabular}{|l}
$\mid$ 補強筋比 \\
(D4@ 105)
\end{tabular} & \\
\hline $1-2$ & NWSM-53-4 & \multirow{2}{*}{$=\mid \begin{array}{c}240 \\
\times \\
240 \\
\end{array}$} & \multirow{2}{*}{$\begin{array}{l}12- \\
\text { D13 }\end{array}$} & $\begin{array}{l}D 6 @ 50 \\
(0.53 \%)\end{array}$ & 40 & 470 & $0.30 \%$ & 24.7 \\
\hline $3-2$ & NWS-89-4.6 佐柱 & & & $\begin{array}{l}D 6 @ 30 \\
(0.89 \%)\end{array}$ & 60 & $\begin{array}{l}\frac{240}{360} \\
240\end{array}$ & $0.20 \%$ & 33.9 \\
\hline & 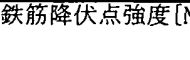 & $7 \mathrm{~mm}^{2}$ & $\begin{array}{l}\text { No } \\
\text { No }\end{array}$ & $\begin{array}{l}1-2:[0 \\
3-2:[D\end{array}$ & & $\sqrt{106}$ & $\begin{array}{l}292],[\mathrm{D} \\
296],[\mathrm{D}\end{array}$ & $\begin{array}{l}250] \\
228]\end{array}$ \\
\hline
\end{tabular}

定着させている。柱せん断補強筋は, No.3-2 試験体で D6@30 $p_{w}=$ 0.89\%)とした。また，スタブ梁主筋は $2 \times 6-\mathrm{D} 22(\mathrm{SD} 295)$ ，せん断補 強筋は D13(SD295)@100( $\left.p_{w}=0.31 \%\right)$ とした。

変動要因は, No.1-2 試験体も含めて，そで壁長さ $\left(l_{w}\right)$ が 3 水準 $(240,360,470 \mathrm{~mm})$, そで壁厚さ $(t)$ が 2 水準 $(40,60 \mathrm{~mm})$, そして, 壁の 接合状況が 2 水準(片側に接合 : 外柱, 両側に接合：中柱)とした。 これらの変動要因が設定されるように，左側柱・中柱・右側柱の 各々で接合するそで壁を変化させている。

加力は, 図 2 の様に加力用鉄骨を介して, 上部に一定の軸力を保 ち, 試験体上部のスタブ梁芯位置に, 左右の押し引きの荷重が等し くなるよう変位制御の漸増繰り返しでせん断力を載荷した。

\section{2 実験結果}

図 3 に破壊状況，表 2 に実験結果一覧を示す。No.3-2 試験体の破 壊は，層間変形角 $\gamma=1 / 800 \sim 1 / 400 \mathrm{rad}$.にかけて，曲げひび割れが 端部に発生し， $\gamma=1 / 800 \mathrm{rad} .(Q=300 \sim 400[\mathrm{kN}])$ を過ぎた変形角で, 柱とそで壁の接合面に一番近い壁緃筋に沿って無数のせん断ひび割 れが発生した。そして， $\gamma=1 / 400 \sim 1 / 200 \mathrm{rad}$. 付近で柱とそで壁が そのひび割れ発生位置で鉛直方向にすべる性状が顕著となり，柱と そで壁の一体性が失われている。その後, 純ラーメン6) と同程度 の変形角である $\gamma=1 / 200 \sim 1 / 100 \mathrm{rad}$.で，柱主筋が引張降伏して柱 曲げ降伏先行型の破壊モードを示し，最大耐力以降，そで壁部のコ ンクリート圧壊が著しくなる性状となった。これら破壊性状は，発 生荷重(変形)に差があるが，左側柱，中柱および右側柱の全てで同 様であった。柱部材は，最終サイクル( $\gamma=1 / 25 \mathrm{rad}$.$) まで軸力を保持$ し，せん断ひび割れが著しく進展せず，健全な性状であった。なお， スタブ梁には，目視ではひび割れが認められない状況であった。

図 4 に層せん断力 $(Q)$ 一層間変位 $(\delta)$ 関係を示す。No.3-2 試験体 の変形性状は，曲げひび割れの発生と共に剛性が低下し，柱とそで 壁が接合面ですべる性状が顕著になることで更に剛性が低下する性

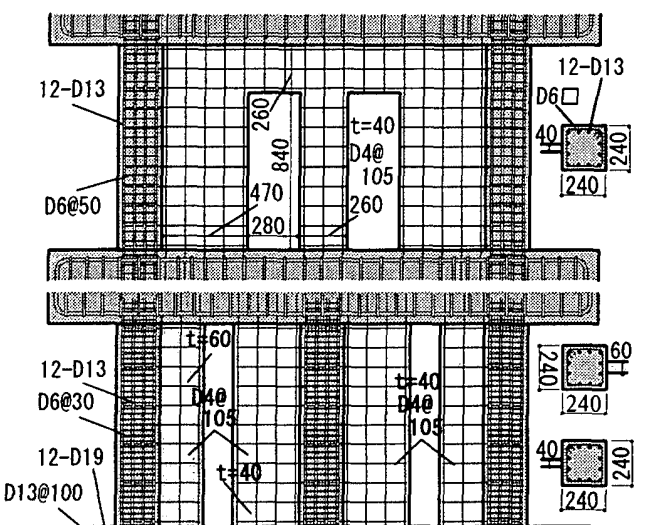

The
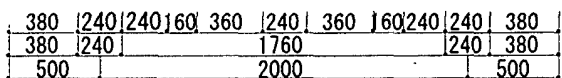

図 1 試験体形状(上：No.1-2 ${ }^{6}$, 下: No.3-2)

表 2 実験特異点一覧 : 正載荷 $(Q[\mathrm{kN}](\delta[\mathrm{mm}]))$

\begin{tabular}{c|c|c|c|c|c}
\hline \multicolumn{2}{c|}{ No. } & $\begin{array}{c}\text { 柱曲げ } \\
\text { ひび割れ }\end{array}$ & $\begin{array}{c}\text { 柱ーそで壁 } \\
\text { 間ひび割れ }\end{array}$ & $\begin{array}{c}\text { 柱主筋 } \\
\text { 引张降伏 }\end{array}$ & $\begin{array}{c}\text { 最大 } \\
\text { 耐力 }\end{array}$ \\
\hline \multirow{2}{*}{$1-2$} & 左柱 & $216(1.75)$ & $137(0.87)$ & $339(10.10)$ & \multirow{3}{*}{346.8} \\
\cline { 2 - 5 } & 右柱 & $297(3.52)$ & $216(1.75)$ & $345(11.08)$ & $(12.12)$ \\
\hline \hline \multirow{2}{*}{$3-2$} & 左柱 & $191(0.87)$ & $418(3.35)$ & $496(7.03)$ & \multirow{2}{*}{510.2} \\
\cline { 2 - 5 } & 中柱 & $290(1.74)$ & $296(1.67)$ & $481(8.74)$ & $(12.03)$ \\
\cline { 2 - 5 } & 右柱 & $304(1.75)$ & $358(2.39)$ & $493(9.22)$ & \\
\hline
\end{tabular}

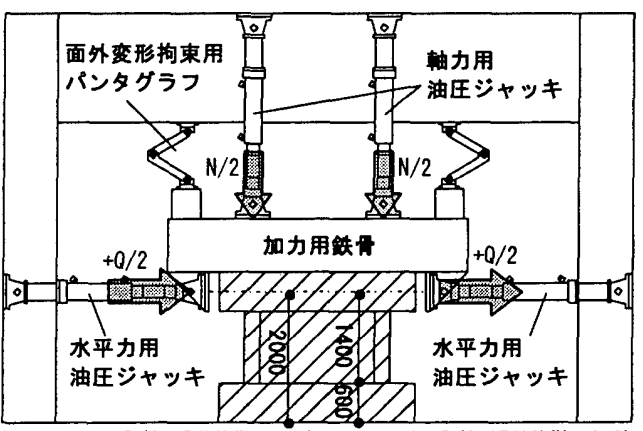

$\mathrm{N}=2 \cdot \sigma_{\mathrm{B}} \cdot D_{c} \cdot B_{d}{ }^{6}=474 \mathrm{kN}\left(\right.$ No. 2-1), $3 \cdot \sigma_{\mathrm{B}} \cdot D_{i} \cdot B_{d} 6=976 \mathrm{kN}($ No. 3-2) 図 2 実験加力装置図
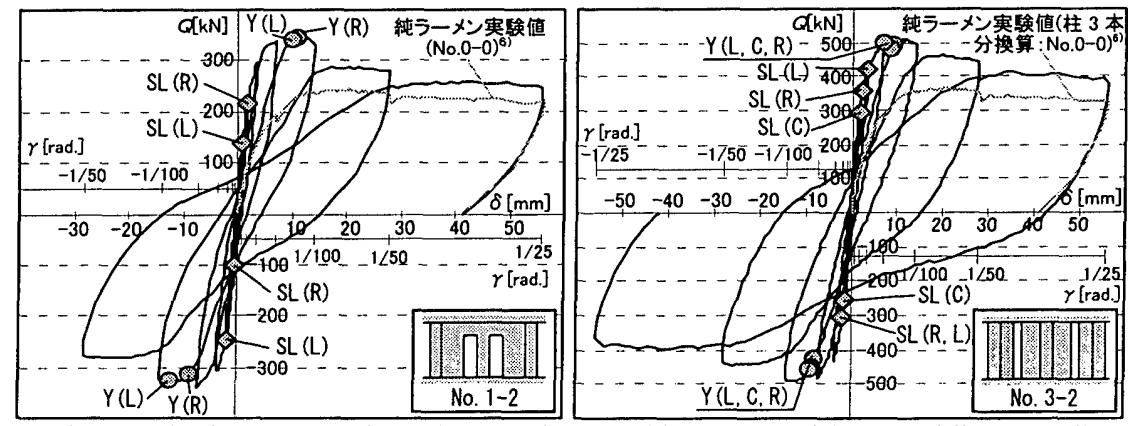

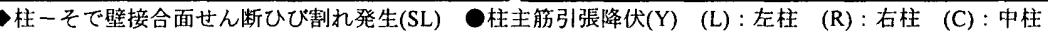

図 4 層せん断力 $(Q)$ 一層間変位 $(\delta)$ 関係 
状であうた。そして，柱主筋の引張降伏により最大耐力を迎え，そ で壁のコンクリートの圧壊が著しくなることで, 純ラーメン(柱部 材のみ)の性状へと徐々に移行することが認められる。

以上の実験結果を検討して, 構造性能評価を行っていく。

\section{3. 有限要素法による数値解析}

柱と壁板のせん断力に対する抵抗機構を明確にするため，内部応 力状態の把握が可能である有限要素法による数值解析を行う。ここ では，解析が実験の状況を表現できていることを検証した後に，実 験を補足する結果を得るため, 擬似的な実験として, 壁厚 $(t)$ とそで 壁長さ $\left(l_{w}\right)$ を変動させたパラメトリック解析を行った。

\section{1 解析概要}

図 5 に要素分割図および接合部要素設定模式図を示す。解析は, コンクリート，鉄筋および付着の材料非線形を考虑した 2 次元有限 要素法解析プログラム ${ }^{9)}$ を使用している。コンクリート要素は, 8 節点四角形の弹塑性要素で, 2 軸応力下の応力度 $(\sigma)$-ひずみ度. $(\varepsilon)$ 関係は Darwin and Pecknoldによる等価一軸ひずみ度に基づく直 交異方性モデルを修正して用い10)，破壊条件は Kuper らの実験結 果を修正した Darwin のモデルを用いた。柱主筋は鉄筋線材要素, 柱と壁のせん断補強筋はコンクリート要素内に一様に分布するとし た鉄筋積層要素(付着完全固定)でモデル化し，柱主筋とコンクリー トの付着は各要素間にボンドリンクを設定してモデル化した。更に， 柱，梁および壁板の各接合面には，局所的なひび割れと鉄筋のダボ 抵抗をモデル化するため，クラックリンクおよび，文献 11）のせ ん断カ一ずれ関倸を適用しだダボリンクを設定した。クラックリン クは，接合面の垂直・水平方向共に完全固定であり，垂直応力度が コンクリート引張強度を超えた後は両方向の剛性および応力を零と した。ダボリンクは，接合面に垂直な方向が完全固定であり，水平 方向は図 5 中に示すバネ特性とした。こ机らのバネは，接合面の応 力伝達をするものであり，意図的に柱とそで壁の接合面にすべりを 発生させる要素としては設定していない。解析の試験体は, No.1-2 試験体のたれ壁を除いた形状であり，そで壁部分の厚さは全て一様 である。材料の機械的特性は，実験の材料試験結果を用いた。

\section{2 解析の検証}

図 6 に実験(No.1-2) と解析 $\left(l_{w}=470 \mathrm{~mm}, t=40 \mathrm{~mm}\right)$ を比較した層せん 断力 $(Q)$ - 層間変位 $(\delta)$ 関倸を示寸。解析の破壊状況は, 実験の曲 げひび割れ・せん断ひび割れの発生状況を良く表現し，柱に沿った そで壁コンクリート要素にせん断ひび割れが発生し，すべり発生の 兆候が見られた。しかし，柱一そで壁接合面に明確なずれ変形を生 じるまでには至らず，層間変形角 $\gamma=1 / 200 \mathrm{rad}$. 付近でそで壁部分の コンクリート圧壊が著しくなり, 誤差が大きくなって解析が終了し た。荷重一変位関係では，柱とそで壁のすべりが著しくなる $\gamma=$ 1/200rad. 付近まで実験と解析が対応寸る結果となっている。また， 図 6 中に示すとおり，柱主筋と柱せん断補強筋の歪み性状も対応す る結果が得られている。これらより，解析試験体は、コンクリート 要素にひび割れが発生するのみでは，そで壁と柱の接合面における すべり性状を十分に表現することができず，このため，柱主筋降伏 まで解析がされていないものと推測される。しかし，柱と壁が一体 である状況の内部応力状態は十分に検討できると思われるので，解 析結果を含めて抵抗機構に対する検討を進める。

\section{3 パラメトリック解析}

壁厚 $(t)$ および壁長さ $\left(l_{w}\right)$ を変動要因とする解析を行い，これら変 動要因が剛性・耐力等に与える変化について検討する。非構造壁の 壁厚および壁長さは，左右の柱で同一としている。

解析結果の剛性および最大耐力一覧を表 3 に, 層せん断力 $(Q)-$ 層間変位 $(\delta)$ 関係を図 6 に示す。解析は, 壁厚 $t=160,240 \mathrm{~mm}$ の解析 試験体のみが引張側柱主筋の降伏で最大耐力に達している。その他 の解析試験体は，柱に沿ってそで壁のひび割れが生じているが，明 確なずれ変位が柱ーそで壁間で生じず，そで壁部分のコンクリート 圧壊が著しくなることで誤差が大きくなり，解析が終了した(解析

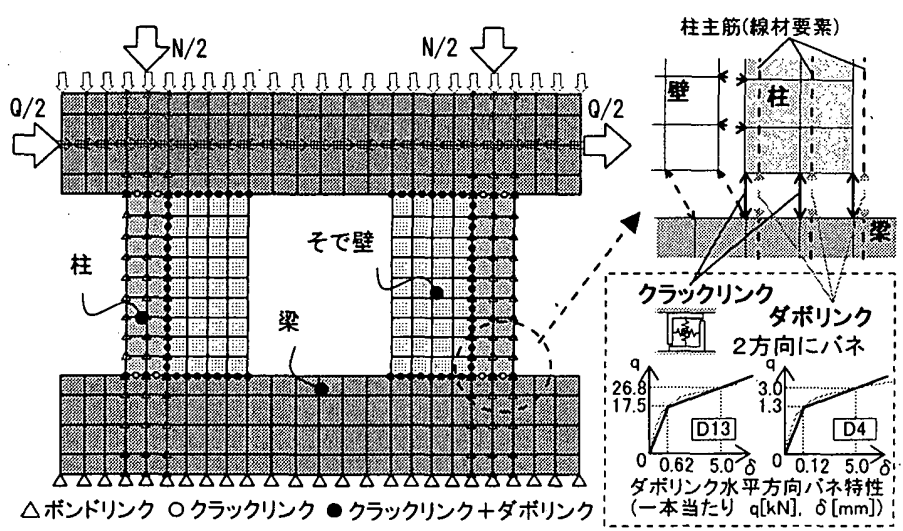

図 5 有限要素法解析要素分割図および接合部要素設定模式図

表 3 解析変動要因および解析結果一覧

\begin{tabular}{|c|c|c|c|c|c|c|c|c|c|c|c|}
\hline 壁長さ $(/)[\mathrm{mm}]$ & \multicolumn{9}{|c|}{470} & \multirow{2}{*}{\multicolumn{2}{|c|}{\begin{tabular}{c|c|c|}
240 & 720 \\
40
\end{tabular}}} \\
\hline 壁厚 $(t)[\mathrm{mm}]$ & 10 & 20 & 30 & 40 & 60 & 80 & 120 & 160 & 240 & & \\
\hline 初期㓮性 $[\mathrm{kN} / \mathrm{mm}]$ & 181 & 212 & 296 & 349 & 442 & 503 & 630 & 730 & 849 & 210 & 486 \\
\hline 最大耐力 $[\mathrm{kN}]$ & 207 & 247 & 243 & 326 & $\overline{384}$ & 464 & 538 & 586 & 603 & 262 & 469 \\
\hline
\end{tabular}
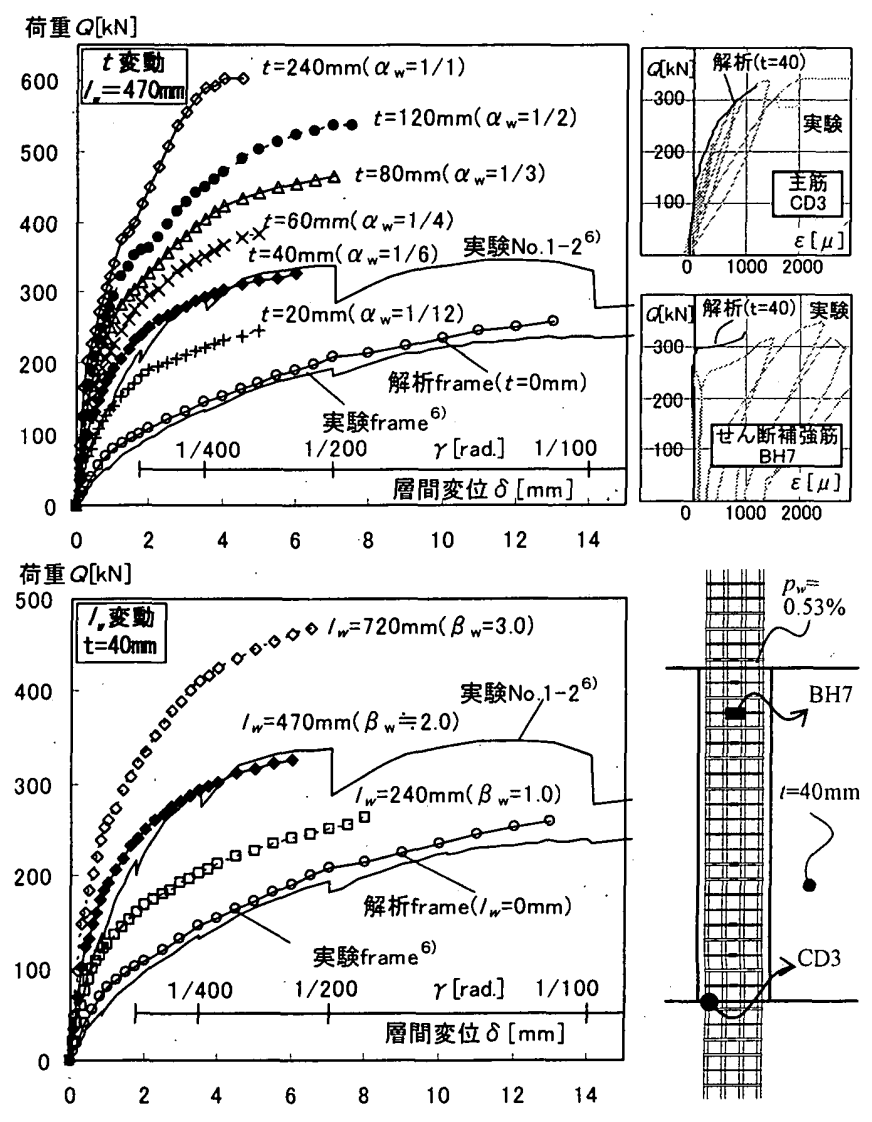

図 6 数値解析結果(層せん断力一層間変位関係) 
終了時を最大耐力とした)。初期剛性は，壁が厚くなる程，または， 壁が長くなる程上昇している。また，最大耐力は，柱主筋が降伏せ ず，そで壁コンクリートが著しく圧壊した試験体では，壁が厚くな る程，または，壁が長くなる程，線形的に上昇する傾向があるが， 柱主筋が引張降伏した試験体では，その上昇がほぼ頭打ちになった。

\section{4. 内部応力状態}

せん断抵抗機構のモデル化を行うため，実験および数值解析結果 より内部応力状態について検討する。なお, 解析結果については, 柱とそで壁が一体である状況を示していると判断する。

\section{1 芯力の流れ}

図 7 は，数值解析結果より得られたコンクリート主応力図である。 図中, 線の長さは圧縮応力の大きさ, 線の方向は主态力方向を示し

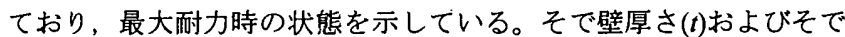
壁長さ $\left(l_{w}\right)$ の変化に関わらず，主応力は，対角を結ぶ方向に存在し ていることが認められる。したがって，構造性能の評価には，柱一 そで壁接合面における応力状態，および，そで壁端部(圧縮縁)にお ける応力状態について着目することが重要と推測される。

\section{2 柱モーメント分布(柱一そで壁接合面垂直応力度)}

図 8 に実験および数值解析の柱各断面におけるモーメント分布を 示す。実験の值は，柱主筋歪みより平面保持を仮定し，材料試験結 果に基づくモデル(図 8 中)を用いて算出している。解析の值は，鉄 筋線材要素およびコンクリート面要素の态力を用いて算出している。

柱のモーメントは, そで壁長さが短い $\left(l_{w}=240 \mathrm{~mm}\right)$ 場合, そして, 両側にそで壁が接合する中柱の場合に直線的な分布を示している。 これは，壁が短い場合は，柱一そで壁接合面で伝達される圧縮(垂 直)応力度が小さく，壁負担のモーメントが小さいためであり，中 柱の場合は両側から伝達される圧縮力がほぼ同じになり，柱せん断 力の変化が小さいためと考えられる。したがって，片側にそで壁が 接合する場合は，壁が厚くなるほど，また，壁が長いほど，柱一そ で壁接合面の圧縮応力度が大きくなり, 柱負担せん断力の変化が著 しく，柱モーメントが曲線的に変化する傾向となる。これら分布状 況より，柱一そで壁接合面の圧縮(垂直)応力度は，ほほ一様に分布 しているものと推測される。なお，これらの状況は，柱とそで壁の すべりが顕著になる層間変形角 $(\gamma=1 / 400 〜 1 / 200 \mathrm{rad}$.)の前後におい て，著しく変化していない。

\section{3 柱ーそで壁接合面せん断応力度分布}

図 9 に数值解析の柱ーそで壁接合面のせん断态力度分布を示す。 接合面のせん断応力度は, クラックリンクおよびダボリンクの要素 応力より求めている。若干，隣り合う節点の值にばらつきがあるも のの，柱頭から柱脚まで平均的に見ると，図に見られるように，壁 厚 $(t)$ や壁長さ $\left(l_{w}\right)$ に関方らず，せん断応力度は，接合面全域に渡り ほほ一様で，最大耐力時で平均 $5 \mathrm{~N} / \mathrm{mm}^{2}$ 程度の分布を示している。 以上より，柱とそで壁の接合面におけるすべりを評価する際，接合 面に発生する応力は一様として評価すればよいと考えられる。

\section{4 そで壁端部ひずみ度分布}

図 10 に実験(No.3-2)のそで壁端部コンクリート歪み分布の一例を 示す。歪み計は, コンクリート表面に貼付しており，梁との接合面 から $50 \mathrm{~mm}$ の壁綐筋位置で計測している。コンクリートの歪みは, 層間変形角 $y=1 / 800 \mathrm{rad}$. 程度まで, 柱部分も含めた断面内の全域で

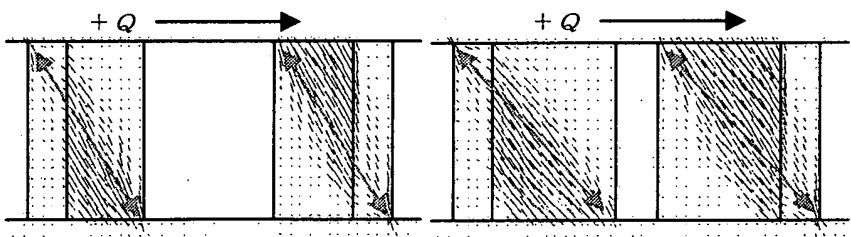

図 7 解析コンクリート主応力図 $\left(l_{w}=470,720 \mathrm{~mm}\right.$ : 左右共 $\left.t=40 \mathrm{~mm}\right)$
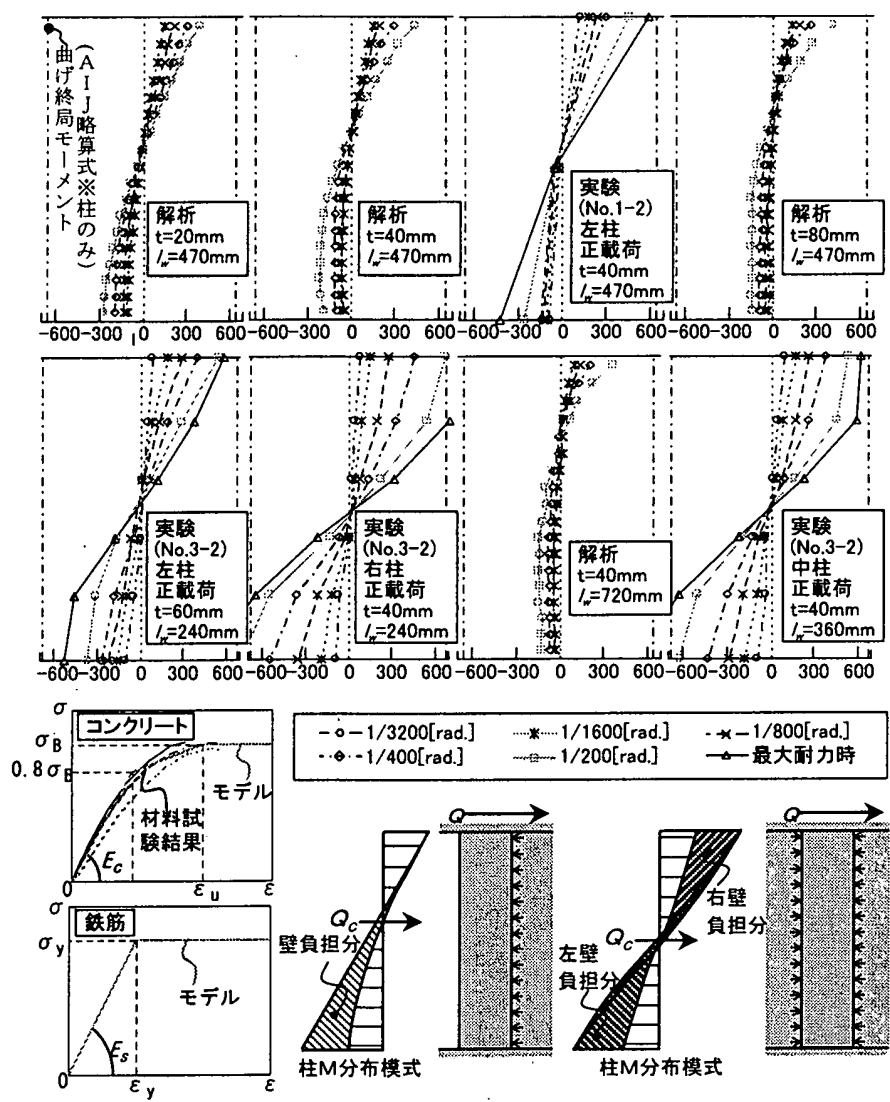

図 8 柱モーメント分布図(単位 $[\mathrm{kN} \cdot \mathrm{m}]$, せん断力は左から右)

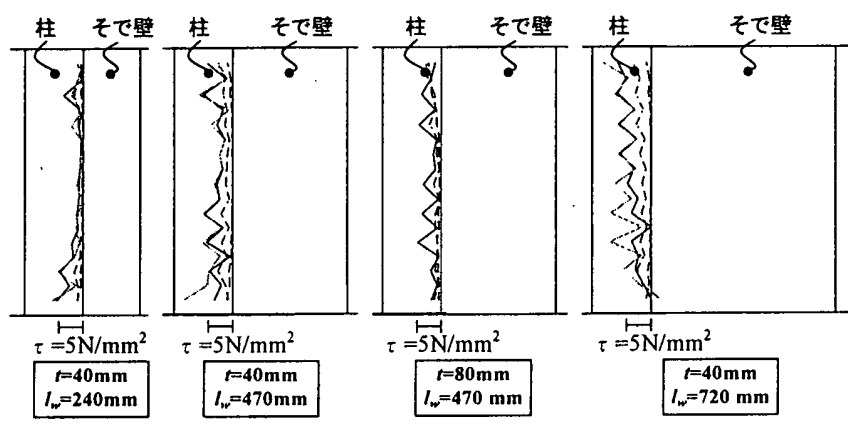

$\cdots \gamma=1 / 1600[\mathrm{rad}]-.\cdots \gamma=1 / 800[\mathrm{rad}$.] $-\gamma=1 / 400[\mathrm{rad}]-.\gamma=1 / 200[\mathrm{rad}$ ] $]$

図 9 柱一そで壁間せん断応力度分布(せん断力は左から右)

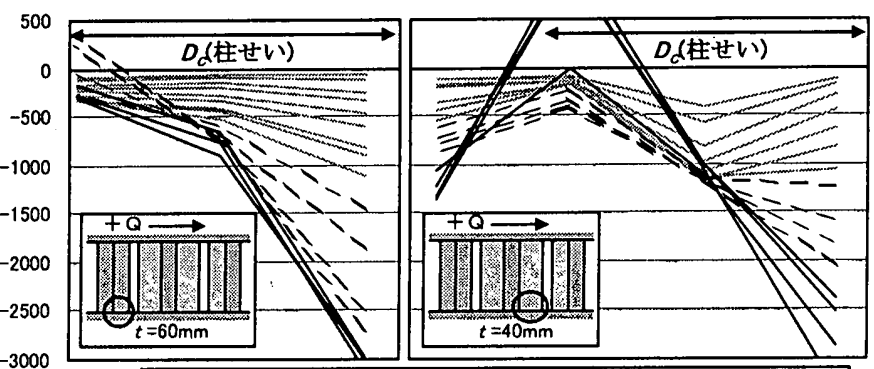

$\varepsilon[\mu]$

図 10 そで壁端コンクリート歪み分布(実験 No.3-2) 
直線に近い分布で発生している。柱に最も近い測定位置では，柱と そで壁のすべりによるせん断ひび割れの影響が見られるが，歪みは， すべりが顕著になり始める $\gamma=1 / 400 〜 1 / 200 \mathrm{rad}$ において，そで壁 端部から $1.0 D_{C}\left(D_{C}\right.$ : 柱せい)の位置で零となる三角形分布の状態へ 移行している。これは，そで壁長さ $\left(l_{w}\right)$ が $360 \mathrm{~mm}$ と長い中柱の場合 も，そで壁長さ $\left(l_{w}\right)$ が $240 \mathrm{~mm}\left(=1.0 D_{C}\right)$ と柱せいと同じである側柱の 場合にも，また，壁厚 $(t)$ が変化する場合も同様な性状が認められる。

\section{5. 構造性能評価}

検討した内部応力状態より柱とぞで壁のせん断力に対する抵抗機 構をモデル化し，架構の復元力包絡線(骨格曲線)，特に，剛性，耐 力，破壊モードおよび変形性能の評価方法について提案する。ここ では，柱とそで壁が一体として挙動する場合，そして，柱とそで壁 が接合面ですべる(スリップ)挙動となる場合を含めて評価する。

本論文では，梁が剛強で鉛直部材(柱部材)の特性が卓越する架構 を対象としているので，架構の復元力包絡線は，各柱の復元力包絡 線をすべて足し合わせることで評価する。そで壁が接合する柱の復 元力包絡線は，基本的に曲げ降伏までを図 11(a)に示す様な bi-linear で評価する。柱とそで壁が接合面ですべる場合，柱の復元力包絡線 は，すべり発生の折れ点を持う tri-linear で評価することとした(図 11(b))。そして, 曲げ降伏後の変形能は, 柱とそで壁が一体として 挙動する場合，最大耐力を維持する部材として変形能 $\left(\delta_{C W_{u}}\right)$ を評価 し, 矩形柱のみの変形能 $\left(\delta_{C u}\right)$ が更に大きい場合は, 矩形柱の変形 能と矩形柱の曲げ耐力へ移行する性状と判断する。これは, 柱のせ ん断補強量が十分な場合，そで壁付柱としてのせん断力は維持でき なくとも，矩形柱としての性能は十分保持されることが報告されて おり例えば12)，これらを考慮したものである。また，柱とそで壁が接 合面ですべる場合, 最大耐力以降, 矩形柱の耐力・変形能へ移行す ると判断する。以上の復元力包絡線をモデル化するため，評価項目 は，初期剛性 $\left(K_{C W I}\right)$ ，二次剛性 $\left(K_{C W_{2}}\right)$ ，曲げひび割れ発生荷重 $(Q$ CWmcr)，柱一そで壁スリップ発生荷重 $\left(Q_{C \text { wslip }}\right)$ ，曲げ耐力 $\left(Q_{C W m y}\right.$ : 柱 とそで壁が一体の場合， $Q_{C W S I m v}$ : 柱とそで壁がスリップした場合, $Q_{C n v}$ : 柱部材のみの場合), せん断耐力( $Q_{C H_{s u}}$ : 柱とそで壁が一体 の場合， $Q_{C s u}$ : 柱部材のみの場合)および限界変形 $\left(\delta_{C W u}:\right.$ 柱とそで 壁が一体の場合， $\delta_{C u}$ : 柱部材のみの場合)とした。

各評価項目について，柱とそで壁のせん断力に対する抵抗機構を 実験結果および解析結果よりモデル化して求める。図 12 は，抵抗 機構の模式図である。抵抗機構は，すべり発生前は，柱と壁板が一
体として抵抗しているものとして，また，すべり発生後は，そで壁 端部に圧縮束が偏るものとして扱う。すべり発生後のそで壁端部コ ンクリート圧縮応力は，柱せい $\left(D_{C}\right)$ と同じ幅で三角形に分布してい るものとする。また，柱一そで壁接合面の忘力は，部材長さ方向全 面で一様に発生しているものと仮定する。なお，垂れ壁・腰壁が接 合する場合, クリアスパン $\left(h_{0}{ }^{\prime}\right)$ の扱いは文献 6$)$ にしたがい, ここ では変動軸力を考慮せず，初期(長期)軸力のみを考慮する。

\section{1 用性}

\subsection{1 初期㓮性}

初期剛性は, 曲げ変形 $\left(\delta_{C m}\right)$ およひびせん断変形 $\left(\delta_{c s}\right)$ より(1)式で求 められる。柱の曲げ変形 $(\delta \mathrm{cm})$ は，部材軸方向 $(\mathrm{y}$ 方向 $)$ の曲率 $(\varphi)$ を 積分して(2)式で算出する, また，柱せん断変形 $\left(\delta_{C s}\right)$ は，せん断力 からせん断変形角を算出し, 部材軸方向で積分して(3)式で求めら れる。ここで断面 2 次モーメント $\left(I_{W}\right)$ ，断面 $\left(A_{W}\right)$ およびせん断形状 係数 $(\kappa w)$ は, 壁が接合する変断面として ${ }^{13)}$ 求める。なお, ここで は，柱部材のモーメントが逆対称であるとして算出している。

$$
\begin{aligned}
& K_{C W}=\frac{Q_{C}}{\delta_{C m}+\delta_{C s}}, K_{C W 1}=\frac{Q_{C}}{\delta_{C m 1}+\delta_{C s 1}} \\
& \delta_{C m}=\iint\{\varphi(y)\} d y d y=\iint\left\{\frac{M_{C}(y)}{E I}\right\} d y d y \quad \delta_{C m 1}=\frac{Q_{C} h_{0}{ }^{3}}{12 E I_{W}} \quad \cdots(1) \\
& \delta_{C s}=\int\left\{\frac{\kappa Q_{C}}{G A}\right\} d y \quad \delta_{C s 1}=\frac{\kappa_{W} Q_{C} h_{0}{ }^{\prime}}{G A_{W}} \\
& E: \text { コシクリートヤング係数 } \quad G=E /(2(1+v)) \quad v=1 / 6 \quad h_{0}{ }^{\prime}: \text { クリアスパン }
\end{aligned}
$$

\section{1 .2 二次剛性（降伏時剛性）}

二次剛性 $\left(K_{\left(W_{2}\right)}\right)$ は，(4)式に示すように，曲げ変形とせん断変形に それぞれ，曲げ剛性低下率 $\left(\alpha_{y}\right)$ およびせん断剛性低下率 $\left(\beta_{u}\right)$ を用い て評価する。曲げ剛性低下率とせん断剛性低下率は，文献 14)より (5)式および(6)式を用いる。なお， $a$ は $h_{0}{ }^{\prime} / 2 ， \eta 。$ は荷重初期に導入 した軸力比(本論文の実験では $1 / 6)$ として計算する。また $p_{t}, p_{w} \sigma_{w v}$ は，矩形柱とした值を用いる。なお，柱とそで壁が接合面でスリッ プする場合，降伏時変形は，壁の接合しない矩形柱と同一とする。

$$
\begin{aligned}
& K_{C W 2}=\frac{Q_{C}}{\delta_{C m 1} / \alpha_{y}+\delta_{C s l} / \beta_{u}} \\
& \alpha_{y}=\left(0.0432+1.635 n p_{t}+0.0434 a / D_{W}+0.325 \eta_{0}\right)\left(d_{W} / D_{W}\right)^{2} \cdots(5) \\
& \beta_{\mathrm{u}}=0.461 p_{w} \sigma_{w y}+0.13 \\
& \text { ここで } D_{W}: \text { 部材全せい, } d_{W}: \text { そで壁圧縮端から柱引張主筋までの距離 }
\end{aligned}
$$

\section{2 各折点荷重（耐力）および破埭モード}

\subsection{1 一次折点 (曲げひび割れ発生荷重).}

第一折点荷重 $\left(Q_{C c r}\right)$ は, クリアスパン上下端に曲げひび割れが発

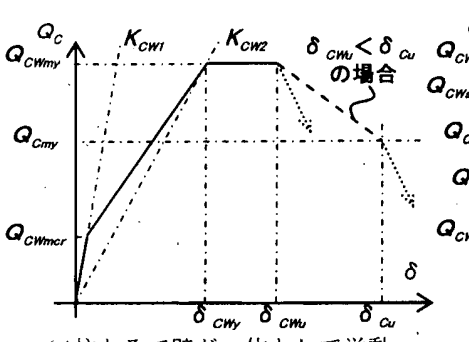

(a)柱とそで壁がーー体として挙動

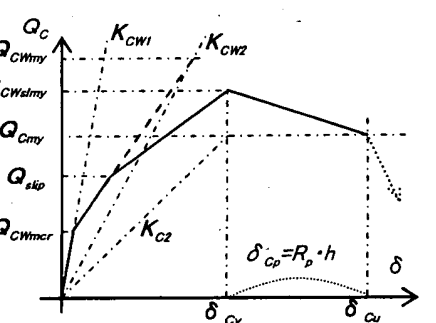

(b)柱とそで壁にすべりが発生

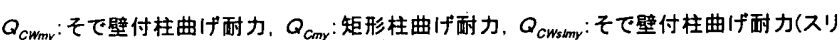

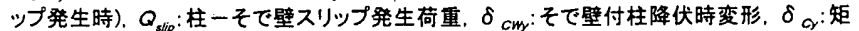
形柱降伏時变形。 $\delta_{\mathrm{cm}}$ : ₹で壁付柱限界変形。 $\delta_{\mathrm{cm}}$ : 矩形柱限界变形

図 11 復元力包絡線のモデル化

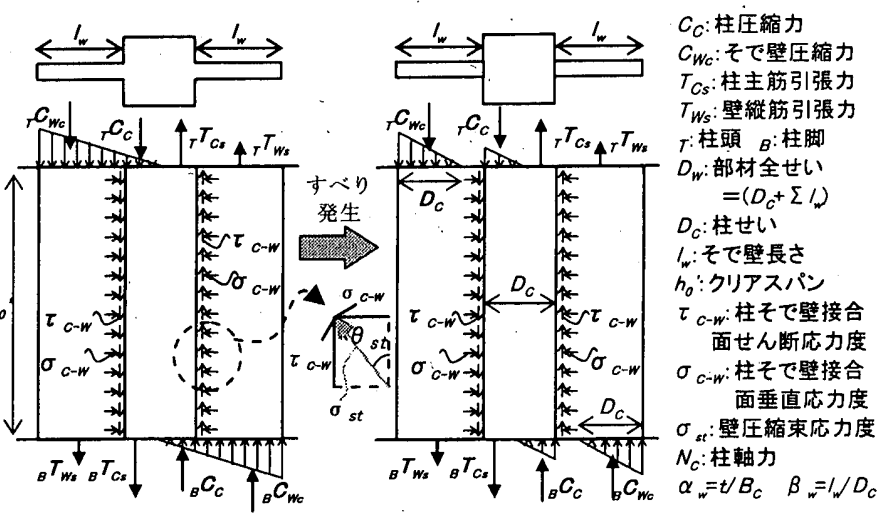

図 12 柱・そで壁抵抗機構概略図 
生した状態を想定して，上下端のモーメントが(7)式 ${ }^{15)}$ のモーメン トに達した時の荷重として，(8)式で求めることとした。

$$
\begin{aligned}
& M_{C W \text { mer }}=0.56 \sqrt{\sigma_{B}} Z_{W}+N D_{W} / 6 \quad Z_{W}=I_{W} /\left(D_{W} / 2\right) \\
& Q_{C W m \text { m }}=2 M_{C W \text { mar }} / h_{0}{ }^{\prime}
\end{aligned}
$$

\section{2.2 二次折点（曲げ耐カ，せん断酎カおよびスリップ発生荷重）}

第二折点(第三折点)荷重 $\left(Q_{C m y}\right)$ は，クリアスパン端部のモーメン トが曲げ終局モーメント $\left(M_{C W y}\right)$ に達した荷重として $(9)$ 式で求められ る。ただし，片側のみにそで壁が接合する場合，(9)'式で求める。

$$
\begin{aligned}
Q_{C W m y}= & 2 M_{C W m y} / h_{0}{ }^{\prime} \quad \cdots(9) \quad Q_{C W m y}=\left(M_{C W m y}+M_{C m y}\right) / h_{0}{ }^{\prime} \cdots(9)^{\prime} \\
こ こ て ゙, & M_{C m y}: \text { 柱断面のみの曲げ終局モーメント }{ }^{15)} \\
& M_{C m y}=0.8 a_{s} \sigma_{y} D_{C}+0.5 N_{C} D_{C}\left(1-N_{C} /\left(B_{C} D_{C} \sigma_{B}\right)\right) \\
& N_{C}: \text { 柱軸力 }\left(\leqq 0.4 B_{C} D_{C} \sigma_{B}\right) \quad a_{s}: \text { 柱引張主筋断面積 } \\
& \sigma_{y}: \text { 柱主筋降伏点強度 } D_{C}: \text { 柱せい } B_{C}: \text { 柱幅 }
\end{aligned}
$$

$M_{C W m v}$ は，柱とそで壁が一体として挙動するとき，壁繸筋を考慮

して $\left(N_{w s}, M_{w s}\right)$ ，累加強度式 ${ }^{7)}$ を修正した(11)式により求める。

$M_{C W m y}=M_{u /} \sim M_{u s}$

$N_{\sigma}=N_{m i n}^{\prime}-a_{n} \cdot \sigma_{y}-2 N_{w s} \quad N_{l}=N_{m i n}^{\prime}-a_{n} \cdot \sigma_{y}+N_{w u} \quad N_{2}=-a_{n} \cdot \sigma_{y}+N_{w u}$ $N_{3}=0.4 B_{C} D_{C} \sigma_{B}-a_{n} \cdot \sigma_{y}+N_{\text {wu }} \quad N_{f}=0.4 B_{C} D_{C} \sigma_{B}+a_{n} \cdot \sigma_{y}+N_{w u}$ $N_{5}=N_{\text {max }}^{\prime}+a_{n} \cdot \sigma_{y}+2 N_{w u}+2 N_{w u} \quad N_{\text {min }}^{\prime}=-2 a_{t} \cdot \sigma_{y}$

$N_{\max }^{\prime}=B_{C} D_{C} \sigma_{B}+2 a_{t} \cdot \sigma_{y} \quad N_{w u}=\eta_{c} t l_{w} \sigma_{B} \quad M_{w u}=N_{w u} \cdot\left(D_{C}+l_{w}\right) / 2$

$N_{w s}=a_{w} \sigma_{s v}\left(=t l_{w} p_{s}\right) \quad M_{w u}=N_{w u} \cdot\left(D_{C}+l_{w}\right) / 2 \quad M_{w s}=2 N_{w s} \cdot\left(D_{C}+l_{w}\right) / 2$

$N_{5} \geqq N_{C}>N_{4}$

$M_{u l}=\left(0.8 a_{t} \sigma_{y} D_{C}+0.12 B_{C} D_{C}^{2} \sigma_{B}+M_{w u}+M_{w s}\right)$

$\cdot\left(N_{\text {max }}^{\prime}+a_{n} \cdot \sigma_{y}+2 N_{w u}+2 N_{w s}-N_{C}\right) /\left(N_{\text {max }}^{\prime}-0.4 B_{C} D_{C} \sigma_{B}+N_{w u}+2 N_{w s}\right)$

$N_{4} \geqq N_{C}>N_{3}$

$M_{u 2}=0.8 a_{1} \sigma_{y} D_{C}+0.12 B_{C} D_{C}^{2} \sigma_{B}+M_{w u}+M_{w s}$

$N_{3} \geqq N_{C}>N_{2}$

$M_{u 3}=\left(0.8 a_{t} \dot{\sigma}_{y} D_{C}+0.5\left(N_{C}+a_{n} \cdot \sigma_{y}-N_{w u}\right) D_{C}\right.$

$N_{2} \geqq N_{C}>N_{1}$

$$
\cdot\left\{1-\left(N_{C}+a_{n} \cdot \sigma_{y}-N_{w u}\right) /\left(B_{C} D_{C} \sigma_{B}\right)\right\}+M_{w u}+M_{w s}
$$

$M_{u f}=0.8 a_{t} \sigma_{y} D_{C} \cdot\left\{1-\left(N_{C}+a_{n} \cdot \sigma_{y}-N_{w u}\right) / N^{\prime}{ }_{\text {min }}\right\}+M_{w u}+M_{w s}$

$N_{1} \geqq N_{C}>N_{0}$

$M_{u S}=\left(M_{w u}+M_{w s}\right) \cdot\left(N_{C}-N_{\text {min }}^{\prime}+a_{n} \cdot \sigma_{\nu}+2 N_{w s}\right) /\left(N_{w u}+2 N_{w s}\right)$

$\eta_{c}$ : そで壁コンクリートの有効圧縮係数 $=0.85 \quad a_{n}$ : 柱中段筋断面積

$a_{w}$ : 壁縦笳断面積 $\sigma_{s y}$ : 壁笳降伏强度 $p_{s}$ : 壁䋛筋比

また，柱とそで壁の接合面にすべりが発生した場合の曲げ耐力 $\left(Q_{C W}\right.$ slmy $\left._{y}\right)$ は，両側そで壁付柱の場合，(12)式にて，片側そで壁付柱 の場合，(12)'式にて求める。

$$
\begin{array}{ll}
Q_{C W s l m y}=2 M_{C W s i m y} / h_{0}{ }^{\prime} & \cdots(12) \\
Q_{C W s l m y}=\left(M_{C W s i m y}+M_{C m y}\right) / h_{0}, & \cdots(12)^{\prime}
\end{array}
$$

$M_{C W s i m y}$ は，そで壁端部のコンクリート圧縮束(図 12 参照)を考慮

し，圧縮縁が圧縮強度に達すると仮定して(13)，(13)'式より求める。

$$
\begin{aligned}
M_{C W s l m y} & =0.8 a_{t} \sigma_{y} D_{C}+0.5 \Delta N_{C} D_{C} \\
& \left(1-\Delta \dot{N}_{C} /\left(B_{C} D_{C} \sigma_{B}\right)\right)+C_{W c}\left(1 / 6+\beta_{w}\right) D_{C}
\end{aligned}
$$

$\left(l_{w}<D_{C}\right.$ の場合 $)$

$$
M_{C W s i m y}=0.8 a_{t} \sigma_{y} D_{C}+0.5 \Delta N_{C} D_{C}
$$

$$
\left(1-\Delta N_{C} /\left(B_{C} D_{C} \sigma_{B}\right)\right)+C_{W c}\left(D_{C} / 2+2 l_{w} / 3\right)
$$

$0 \leqq \beta_{w} \leqq 2 \quad N_{C} \leqq 0.4 B_{C} D_{C} \sigma_{B} \quad \Delta N_{C}=N_{C}-C_{W C} \quad C_{W C}$ ：そで壁負担圧縮力

$$
C_{W C}=t D_{C} \sigma_{B} / 2 \quad\left(D_{C} \leqq I_{w} \text { のとき }\right) \quad C_{W c}=t l_{w} \sigma_{B} / 2 \quad\left(D_{C}>l_{w} \text { のとき }\right)
$$

せん断耐力は，矩形柱 $\left(Q_{C s u}\right)$ とそで壁付き柱 $\left(Q_{C W s u}\right)$ に分類し，矩 形柱は終局強度型耐震設計指針せん断耐力式 ${ }^{16)}$ を用いて(14)式で, そで壁付き柱は益尾・神野式 7)を用いて(15)式で求める。柱とそで 壁が接合面ですべる場合は，矩形柱として(14)式を用いる。

$$
\begin{gathered}
Q_{C s u}=B_{C j} p_{w} \sigma_{w y} \cot \phi+\tan \theta(1-\beta) B_{C} D_{C} \nu \sigma_{B} / 2 \\
\nu=v_{0}=0.7-\frac{\sigma_{B}}{200} \quad \beta=\frac{\left(1+\cot ^{2} \phi\right) p_{w} \sigma_{w y}}{\nu \sigma_{B}} \\
\tan \theta=\sqrt{\left(h_{0}^{\prime} / D_{C}\right)^{2}+1}-h_{0}^{\prime} / D_{C}
\end{gathered}
$$

$$
\begin{aligned}
& \cot \phi=\min \left(2.0, j_{t} /\left(D_{C} \tan \theta\right) \cdot \sqrt{\nu \sigma_{B} /\left(\mathrm{p}_{w} \sigma_{w y}\right)-1.0}\right) \\
& Q_{C w_{s u}}=B_{C j_{t}} \nu_{s} p_{w} \sigma_{w y}+\tan \theta(1-\beta) A_{a r} \nu_{c} \sigma_{B} / 2 \\
& \beta=2 v_{s} p_{w} \sigma_{w y} /\left(v_{c} \sigma_{B}\right) \quad \tan \theta=\sqrt{\left(h_{0} / D_{a r}\right)^{2}+1}-h_{0}{ }^{\prime} / D_{a r} \\
& v_{c}=1.0-\sigma_{B} / 170 \quad \sigma_{B}<85\left[\mathrm{~N} / \mathrm{mm}^{2}\right] \\
& =42.5 / \sigma_{B} \quad \sigma_{B} \geqq 85\left[\mathrm{~N} / \mathrm{mm}^{2}\right] \\
& D_{a r}: \text { アーチ機構のせい, } A_{a r}: \text { アーチ機構の断面積 } \\
& D_{a r}=\left(1+2 \zeta \beta_{w}\right) D_{C} \quad A_{a r}=B_{C} D_{C}+2 \zeta \beta_{w} D_{C} \quad \text { (両側そで壁) } \\
& D_{a r}=\left(1+\zeta \beta_{w}\right) D_{C} \quad A_{a r}=B_{C} D_{C}+\zeta \beta_{w} D_{C} \quad \text { (片側そで壁) } \\
& \zeta \text { :そで壁のせん断有効係数 }(=0.65) \quad v_{\mathrm{s}} \text { ：せん断補強筋有効係数 } \\
& v_{s}=1.0 \\
& p_{w} \sigma_{w y} / \sqrt{\sigma_{B}} \leqq 0.66 \text { 時 } \\
& =1.28-0.42 p_{w} \sigma_{w y} / \sqrt{\sigma_{B}} \quad 0.66<p_{w} \sigma_{w y} / \sqrt{\sigma_{B}} \leqq 1.53 \text { の時 } \\
& =0.98 \sqrt{\sigma_{B}} / p_{w} \sigma_{w y} \quad 1.53 \leqq p_{w} \sigma_{w y} / \sqrt{\sigma_{B}} \text { の時 }
\end{aligned}
$$

柱ーそで壁接合面のすべりは，柱一壁接合面にひび割れが生じる ことで発生するど考える。そのときの接合面せん断応力度 $(\tau$ c.W $=$ $\left.\tau_{s 1}\right)$ は, 接合面に発生している垂直応力度 $\left(\sigma_{C-F}=\sigma_{0}\right)$ とコンクリー 卜割裂強度 $\left(\sigma_{1}\right)$ を用いて $(16)$ 式で求められる。 $\sigma_{0}$ は, 図 12 の力の 釣り合いより, 压縮束 $\left(\sigma_{s t}\right)$ の角度 $\left(\theta_{s t}\right)$ を用いて $\sigma_{0}=\tau_{s l} \cdot \tan \theta_{s t}$ が成 り立つので, (16)式より(16)'式が求められる。ここで, 図 7 の応力 状態より, 圧縮束 $\left(\sigma_{s l}\right)$ の角度 $\left(\theta_{s t}\right)$ は, 柱頭・柱脚の加力端を結ぶ と仮定して $\tan \theta{ }_{s t}=D_{w} / h_{0}{ }^{\prime}=\left(D_{C}+\Sigma l_{w}\right) / h_{0}{ }^{\prime}$ と考える。

なお，壁補強筋量 $p_{s} \sigma_{s y}\left(p_{s}\right.$ : 壁横筋， $\sigma_{s v}$ : 壁筋降伏点強度)が $\sigma_{\text {， }}$ よりも大きい場合，接合面近傍のひび割れの口開きを抑えられると 考えられるので，(16)'式中の $\sigma$ を $p_{s} \sigma_{s y}$ と読み替えて用いる。

$$
\begin{aligned}
\tau_{s l} & =\sqrt{\sigma_{t}{ }^{2}+\sigma_{i} \cdot \sigma_{0}} \\
\tau_{s l} & =\left(\tan \theta_{s t}+\sqrt{\tan ^{2} \theta_{s t}+4}\right) \sigma_{t} / 2
\end{aligned}
$$

$\tau_{s l}$ より,すべりが発生する時のそで壁脚部圧縮力 $C_{W c(s) l}$ は, 接 合面に一様な応力が生じていることから(17)式で求められる。

$C_{W C(s)}=\tau_{s s} h_{0}^{\prime} t$

柱とそで壁が一体の場合，曲げ降伏時のそで壁脚部圧縮力 $C_{W c(m v)}$ は, (11)式の累加強度式より，そで壁に入力される軸方向力を算出 して(18)式で求められる。(18)式の前者は，そで壁コンクリート圧 壊 $\left(N_{w u}\right)$ によ，後者は柱引張主筋降伏により曲げ耐力に至ること を想定している。なおここでは，そで壁縌筋を無視している。

$$
C_{W C(m y)}=\min \left(0.85 \sigma_{B} t l_{w}, a_{t} \cdot \sigma_{y}+a_{n} \cdot \sigma_{y}+N_{C}\right)
$$

$a_{t}$ : 柱引張鉄笳断面積 $a_{n}$ : 柱中間笳断面積 $\sigma_{y}$ : 柱主筋降伏強度

したがって，柱一そで壁のスリップ発生荷重 $\left(Q_{\text {slip }}\right)$ は，柱とそで 壁が一体として挙動する場合の曲げ耐力 $\left(Q_{C W m y}\right)$ と線形の関係にあ るとして，比をとって(19)式で求められる。

$$
Q_{s(i p}=\left(C_{\left.w_{c}(s)\right)} / C_{w_{c}(m y)}\right) \cdot Q_{C W m y}
$$

破壊モードは，せん断耐力 $\left(Q_{C W s u}\right)$ よりも曲げ耐力 $\left(Q_{C m y}\right)$ が小さい 場合に曲げ降伏先行型と判断する。また，柱とそで壁が一体として 挙動する場合の曲げ耐力 $\left(Q_{C m y}\right)$ よりもスリップ発生荷重 $\left(Q_{s l i p}\right)$ が小 さい場合は，柱とそで壁の接合面ですべりが発生するものと判断し， この時, 矩形柱のせん断耐力 $\left(Q_{C s u}\right)$ よりもスリップ発生時曲げ耐力 $\left(Q_{C \text { CWlmy }}\right)$ が小さい場合に曲げ降伏先行型となると判断する。

\section{2.3 変形能}

変形能は, せん断余裕度による評価等, 様々な算出方法 ${ }^{17)}$ があ

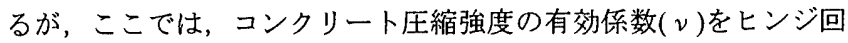
転角 $\left(R_{p}\right)$ にて低減する終局強度型耐震設計指針せん断耐力式勒性式 $\left(v=\left(1.0-15 R_{p}\right) \nu_{0}\right)^{16)}$ に準じて求め，せん断耐力(勒性式)が曲げ耐 力を下回る点を限界変形と判断する。このときの限界変形 $\left(\delta_{u}\right)$ は, 降伏時変形 $\left(\delta_{y}\right)$ および部材長さ $\left(h=h_{0}{ }^{\prime}\right)$ より，(20)式にて求められる。 
表 4 計算結果一覧

\begin{tabular}{l|c|c|c|c|c|c|}
\hline & $K_{\text {cWi }}$ & $K_{\text {CW2 }}$ & $Q_{\text {mer }}$ & $Q_{\text {cwmi }}$ & $Q_{\text {Slip }}$ & $Q_{\text {cwstmv }}$ \\
\hline
\end{tabular} \begin{tabular}{l|l|l|l|l|l|l|l}
\hline 左柱 & 178 & 73 & 75 & 216 & 88 & 150 \\
\hline
\end{tabular}

\begin{tabular}{l|l|l|l|l|l|l}
\hline 䂞挂 & 241 & 111 & 90 & 259 & 78 & 180 \\
\hline \hline
\end{tabular}

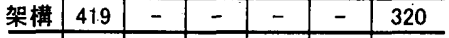

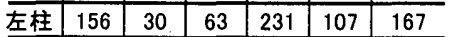

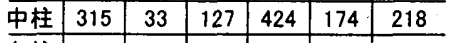
\begin{tabular}{l|l|l|l|l|l|l}
\hline 乭柱 & 126 & 24 & 58 & 231 & 98 & 154 \\
\hline
\end{tabular}

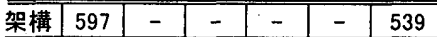
※上段:No.1-2 下段:No.3-2 $K_{C w}:$ 初期剛性, $K_{C w:}:$ 降伏時骩性 $[\mathrm{kN} / \mathrm{mm}]$ $Q_{m c r}:$ 曲げひび割れ発生荷重， $Q_{C m m y}:$ 曲げ 耐力(一体)， $Q_{\text {Ship }}:$ スリップ発生荷重。

$Q_{C w_{s / m y}}:$ 曲げ耐カ(スリップ発生後) $[\mathrm{kN}]$

$$
\delta_{u} \doteq \delta_{y}+\delta_{p}=\delta_{y}+R_{p} \cdot h
$$

ここで，そで壁が一体の場合の $\delta_{C W u}$ は， $Q_{C W m y}>Q_{C W s u}$ となる変形 であり，矩形柱の場合の $\delta_{C u}$ は， $Q_{C m y}>Q_{C s u}$ となる変形である。

\section{6. 構造性能評価法の適合性}

\section{1 本論文の実験に対する検証}

表 4 に計算値一覧を，図 13 にせん断力一層間变位関倸包絡線に おける計算値と実験值の比較を示す。架構の計算值は，柱のせん断 力一層間変位関倸包絡線を総和して求めている。図 13 では, 点線 が各柱の包絡線(計算値)を示しており，実線が架構全体の包絡線 (計算値)を示している。計算値に用いた材料強度, ヤング係数は, 全て材料試験結果の值を用いている。

せん断力一層間変位関係において, 本論文の計算方法は, 初期剛 性をやや高めに評価(比較值 $0.51 \sim 0.56$ ) しているが, 剛性の低下状 況, 降伏時変形および最大耐力(比較值 $0.95 \sim 1.08$ )を良好に評価し ている。スリップ発生荷重についても計算值(比較値 0.78〜1.38)は, 実験を適切に評価している。なお，変形能は，全体的に安全側の評 価であるが，概ね実験結果と対応する適合性を示している。

\section{2 本論文の数值解析に対する検証}

初期剛性および最大耐力の数値解析結果と計算値の比較を図 14 に示す。最大耐力の比較值には; 累加強度式(一体の場合)の曲げ耐 カ $Q_{C W m}$, スリップが発生した場合の曲げ耐力 $Q_{C W s \operatorname{smy}}$, 柱一そで壁 スリップ発生荷重 $Q_{\text {CHsip }}$ の計算值も示した。横軸は, 壁厚の柱幅に 対する比 $\left(\alpha_{w}=t / B_{C}\right)$ としている。

初期剛性の計算値は, 若干高めではあるが，壁が厚くなることに よる剛性の上昇と対応しており，適切に評価されている。

壁厚 $(t)$ が $120 \mathrm{~mm}\left(t / B_{C}=1 / 2\right)$ 以下の場合，解析は，柱接合面近傍の そで壁コンクリート要素にひび割れが生じているものの，接合面に おけるスリップを十分にモデル化できていないため；そで壁コンク リートの圧壊が著しくなり，柱主筋降伏(曲げ耐力に達する)まで至 っていない。これら解析試験体は，曲げ耐力(累加強度式)計算值よ りもスリップ発生荷重計算值が小さくなっており，この状態を適切

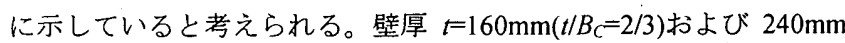
$\left(t / B_{C}=1,0\right)$ の場合, 解析においても柱主筋降伏が観察され，ほほ曲 げ耐力計算值(累加強度式)まで解析されている。これらの性状は; 壁長さが変化した場合についても同様であり，本論文の方法は，壁 厚・壁長さの変動に対応した評価法といえる。

\section{3 既往の実験研究に対する検証}

既往研究の実験 7)．8）．18)－35)を用いて検証する。検証試験体は,

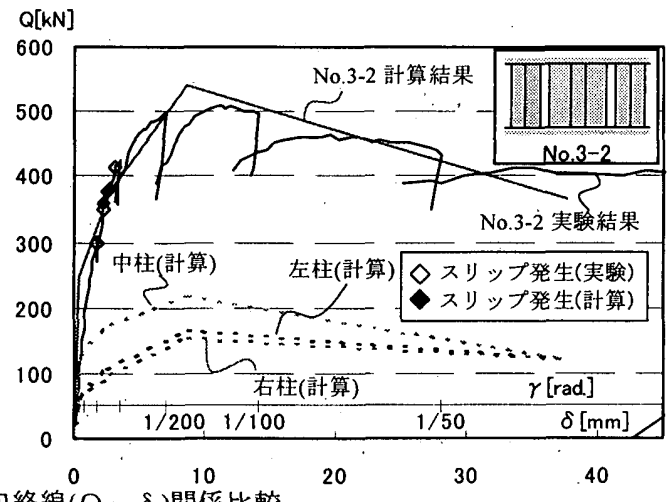

図 13 実験一計算包絡線 $(Q-\delta)$ 関倸比較

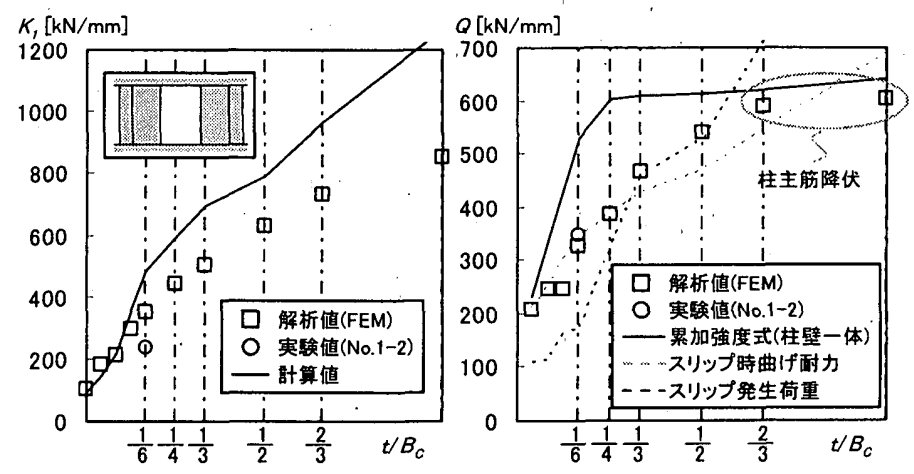

図 14 解析值一計算值比較(初期剛性 $K_{I} \cdot$ 耐力(最大荷重) $Q$ )

架構試験体および部材試験体を抽出している。既往研究では, 変形 について報告されているものは少ないので,ここでは, 曲げ耐力, せん断耐力, 柱破壊モードの判定および壁スリップ発生の有無につ いて検証する。試験体の破壊モードは，柱曲げ降伏先行型または柱 せん断破壊先行型であり； スリップが発生した(スリップ後の曲げ 降伏，スリップ後のせん断破壊)試験体を含めている。なお，曲げ 降伏先行型には，そで壁コンクリートが圧壊した試験体も含んでい る。試験体を抽出した論文は, 壁が付帯しない基淮試験体(矩形柱 試験体または frame 試験体)の曲げ耐力(最大耐力)が著しく計算值 (AIJ 曲げ略算式)と異なる論文(比較值が 0.85 以下または 1.15 以上) を除いている。抽出した試験体数は, 本論文の実験を含め 105 体で ある。試験体の主な要因の範囲は，以下に示寸とおりである。

壁厚・柱幅比 $\left(\alpha_{\mathrm{w}}=t / B_{C}\right): 0.13(1 / 7.5) \sim 0.48(=1 / 2.08)$ ，壁 長さ・柱幅比 $\left(\beta_{\mathrm{w}}=l w / D_{C}\right): 0.48 \sim 3.00$, コンクリート圧 縮強度 $\left(\sigma_{\mathrm{B}}\right): 14.8 \sim 33.9\left[\mathrm{~N} / \mathrm{mm}^{2}\right]$, 軸力比 $\left(\eta=N_{C} / \sigma_{\mathrm{B}} B_{C}\right.$ $\left.D_{C}\right): 0.00 \sim 0.40$, 柱せん断補強筋比 $\left(p_{w}\right): 0.10 \% \sim 1.21 \%$

図 15 に曲げ耐力 $\left(e Q_{m y},{ }_{c} Q_{m y}\right)$ とせん断耐力 $\left(e Q_{s u, c} Q_{s u}\right)$ の実験值(最 大耐力)と計算值の比較を示す。

柱とそで壁が一体として挙動する場合の曲げ耐力は, 試験体スケ 一ルが小さい場合に若干バラツキがあるが，実験值と計算值の比が 大部分において $0.8 \sim 1.2$ の間に分布しており，良好な対応を示して いるといえる。スリップの生じている場合の曲げ耐力は，比の平均 が 1.09 と実験值と良好な対応をしており，累加強度式を用いて計 算した場合 $(\bigcirc ：$ 灰色)に比べて適切に評価がなされている。

せん断耐力も同様に，試験体スケールが小さい場合にバラツキが 大きいが，実験值の大部分は計算值の 0.8〜1.2 倍に収まっており， 十分精度のある評価がなされている。また，スリップ発生後にせん 断破壊した試験体についても，数が少ないが評価可能と考えられる。 

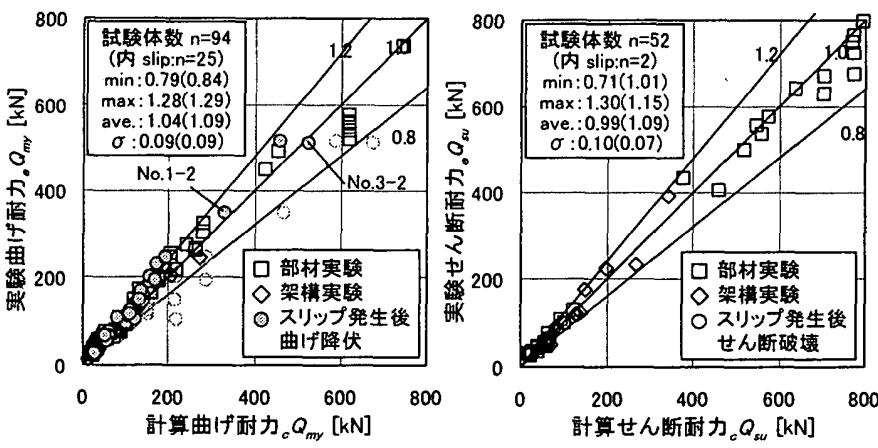

図 15 実験值一計算值比較(曲げ耐力 $Q_{m y} \cdot$ せん断耐力 $Q_{s u}$ )

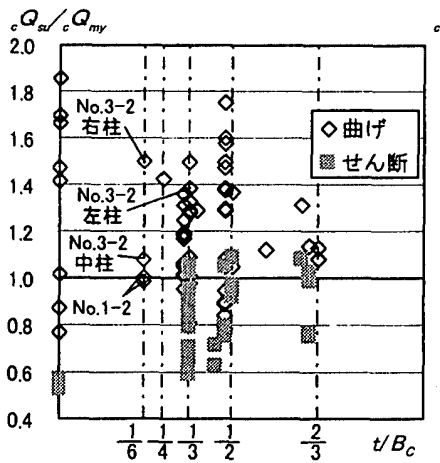

(a)せん断余裕度と柱破壊モード

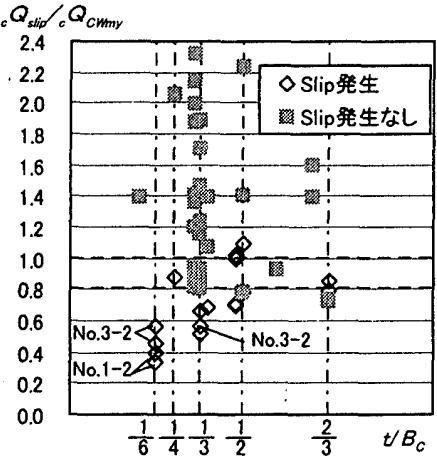

(b) $Q_{\text {slip }} / Q_{C W m y}$ とスリップ発生有無
図 16 既往実験における計算余裕度と破壊モード

図 16(a)に計算柱せん断余裕度(柱せん断耐力/柱曲げ耐力 $={ }_{c} Q_{s u} / c$ $\left.Q_{m v}\right)$ と柱破壊モードの関倸を示す。図には矩形柱の結果も示して いる。せん断破壊先行型と曲げ破壊先行型の境界は，壁厚に関係な く余裕度が 1.0 の時とみてとれる。なお；余裕度が 1.0 を越える領 域でもせん断破壊を示す試験体が存在するが，それらの試験体は， せん断破壊時の耐力と曲げ耐力計算值がほぼ同じであることから， 曲げ降伏とせん断破壊がほぼ同時に発生していると推測される。

図 16(b)に計算スリップ発生荷重 $\left({ }_{c} Q_{C W s}\right) /$ 計算柱曲げ耐力 $\left.{ }_{c} Q_{C W m y}\right)$ と壁破壊モードの関倸を示す。試験体は，曲げ降伏先行型について 抽出している。1.0 を境界としてスリップ発生の有無が判定される ものと考えられる。文献に示された結果のみでは，スリップ発生の 有無が明確でないため, $0.8 \sim 1.0$ 程度の範囲内ですべりが発生して いない試験体も存在する。これは，評価式がひび割れ発生をスリッ プ発生時と評価しており，ひび割れ発生後も柱とそで壁が完全にす べるには，若干の荷重の上昇が必要であるとも考えられる。この場 合も含めて，すべり発生荷重を曲げ耐力の 0.8 以下にすることで, 柱と壁板のすべり発生を保証でき，そで壁が剛接合する場合でも， 柱単体の性能とみなした設計が可能であるといえる。

なお，評価法の適用範囲は，実験により検証された範囲である。

\section{7. 結論}

本論文では, 構造体(柱部材)と非構造壁の応力伝達を許容した設 計手法の確立を目的に，そで壁的挙動を示す非構造壁を内蔵する架 構の構造性能（剛性，耐力，破壊モードおよび変形能）評価法を提 案した。本手法は，実験および解析から柱と壁板の応力伝達状況を 顕在化し，せん断抵抗機構をモデル化して構築しており，破壊モ一 ドを適切に分類することで，実験を良く表現できる事を示した。
考文薄

1) 日本建築学会 : 1968 年十勝沖地震被害調查報告, 1968.12，1978 年営城沖地 震災害睭查報告,1980.2，1995 年兵庫県南部地震鉄笳コンクリート造建案 物の地震被害調查報告書, 1997.3 等

2）日本建築学会：1995 年兵庫県南部地震鉄筋コンクリート造建築物の被害調 查報告書，第 IV 編集合住宅 pp. 69,163, 第 VI編非棈造部材 pp.67 76, p . 31,39,102 103，1997.3，阪神・淡路大震災之今後 $の \mathrm{RC}$ 構造設計一 特徵的被害の原因と設計一の提案一,pp.430 435，1998.10 等

3) 日本建築センター: 建築物の䊗造規定 1997年版, 1997

4) 日本建築防災協会：既存鉄笳コンクリート造建築物の耐震診断基整 耐要 改修設計指針・同解説, 1990

5) 日本建築学会耐震壁小委員会二次壁ワーキンググループ：構造目地を設け た鉄筋コンクリート造二次壁に関する研究資料, 1988.3

6) 杉山智昭,松崎育弘,中野克彦: 非構造壁を内蔵する鉄筋コンクリート造架構 の構造性能に関寸る研究，日本建築学会構造系論文集，第 551 号, pp. 111〜 $118,2002.1$

7) 益尾潔,神野靖夫 : 袖壁貫通型アンカーを用いた柱のみの CFRP シート巻き 付け構法による袖壁付き RC 柱の補強効果, 日本建築学会構造系論文集, 第 536 号, pp.121 128, 2000.10

8）磯雅人、松崎育弘、園部泰寿,中村洋行 : 連続繊維シートによりせん断補強され た袖壁付き RC 柱のせん断終局耐力評価，日本建築学会構造系論文集，第 542 号, pp. $147 \sim 154,2001.4$

9)張要暉野口博 : RC 造柱のせん断終局強度に及ぼす軸力の影響に関する解 析的研究コンクリート工学年次論文報告集 Vol.12No.2.pp.329〜332, 1990 析的研究, コンクリーー上工学年次論文報告集,Vol.12,No.2,pp.329 332, 1990
0) Darwin D. and D. A. Pecknold : Inelastic Model for Cyclic Biaxial Loading of Reinforced Concrete, SRS No.409, Civil Engineering Sudies, University of Illinois, 1974.7

11) 大淵英夫,松崎育弘,中野克彦: ずれ変形を考庶したプレキャスト部材接合 面におけるせん断伝達に関する研究，日本建築学会構造系論文集，第 491 号 pp.97 pp. 104, 1997.1

12) 日本建築学会 : 鉄筋コンクリート終局強度設計に関する資料，1987

13) 大久保全陸,東洋一,飯由研 : 腰壁，たれ壁付き鉄筋コンクリート梁の弹塑 性举動に関する実験的研究 (その2。用性および終局強度曲げ強度に関する 考察)，日本建築学会論文報告集，第 207 号，pp.9 17, 1973.5

14）菅野俊介：鉄筋コンクリート部材の復元力特性に関する実験的研究，東京 大学博士論文, 1970.12

15) 日本建築学会：鉄筋コンクリート構造計算規染・同解説, 1999

16) 日本建案学会：鉄筋コンクリート造建物の終局強度型耐震設計指針・同解 説, 1990

17) 日本コンクリートエ学 : コンクリート構造物の勒性とその評価法に関する コロキウム, 1988.3

18）佐藤和英，野村設郎座間美和：た九壁，袖壁を有する鉄筋コンクリート構 造物の弾塑性性状に関する研究，日本建築学会関東支部研究報告集，<構造 系>pp.149 152，1979

19）佐藤和英,野村設郎,座間美和,山田隆久：たれ壁，袖壁，腰壁を有する鉄筋 コンクリート構造物の弹塑性性状 (その1 : 実験および解析概要)，日本建 築学全関東支部研究報告集, pp. $161 \sim 164,1980$

20）座間美和,野村設郎,传藤和英,山田隆久：たれ壁，袖壁，腰壁を有する鉄筋 コンクリート構造物の弾塑性性状（その 2 : 実験および解析結果と考察）, 日本建筑学会関東支部研究報告集, pp.165 166, 1980

21）山田隆久,野村設郎,平間敏彦：た札壁，袖壁，腰壁が周辺部材に及ぼす影 響，日本建築学会大会学術講演梗概集，〈構造系>,pp.1449 1450, 1981

22）長谷川雅弘,野村設郎：鉄筋コンクリートたて開口壁の耐震性能に関する 研究, 日本建築学会大会学術講演梗概集, <構造系>,pp.1909 1910,1984

23）武田寛：鉄筋コシクリート造雑壁付き柱の耐力およひ変形性状に関する実 験的研究，日本建築学会大会学術講演梗概集，〈構造系>,pp.1753 1754,1984

24）武田寛：鉄筋コンクリート造袖壁付き柱の耐力・変形性能に関する実験 (高強度せん断補強筋比の場合)，日本建築学会大会学萿講演梗概集，〈構造 系>,pp.561 562, 1985

25）大久保全陸,東洋一,饭田研：腰壁，たれ壁付き鉄筋コンクリート梁の弾塑 性挙動に関する実験的研究（その1・実験概要および曲げ破壊性状），日本 建築学会論文報告集，第 204 号，pp.1 7, 1973.2

26）大久保全陸,東洋一，鉄筋さンクリート袖壁付き柱の逆対称繰り返し加力 実験 (その 1 : せん断補強筋の少ない場合)，日本建築学会学術講演梗概集， 構造系>,pp.1405 1406, 1973

27）藤又康,果洋一,大久保全陸：鉄筋コンクリート袖壁付き柱の逆対称繰り返 し加力実験 (その2: 壁厚の異なる場合, 袖壁を付加して補強する場合), 日本建䓩学会学術檴演梗概集, <構造系>,pp.1289 1290, 1974

28）大久保全陸,東洋一：鉄筋コンクリート短柱の崩壊防止に関寸る総合研究 (その 9: CW シリーズ: 袖壁付き柱の実験)，日本建築学会大会学術譿演 梗概集，〈構造系>,pp.1305 1306，1974

29）山根一博,東洋一大久保全陸,山本嘉孝,礒健一：鉄筋コンクリート短柱の崩 壊防止に関する総合研究（その37CWシリーズ: 袖壁付き柱の第 2 次夷 験)，日本建築学会大会学術講演梗概集,構造系>,pp.1417 1418,1976

30) 王子和臣, 入江善久,藤本一郎：袖壁付き鉄筋コシクリート柱の举動に関す る実験的研究」，日本建築学会大会学術講演梗概集，pp.1433～[434，1976

31）王子和臣,入江善久,藤本一郎：袖壁付き鉄筋コンクリ一ト柱の挙動に関す る実験的研究 (その 2$)$, 日本建築学会大会学術講演梗概集, 〈構造系〉, pp. $1587 \sim 1588,1977$

32）野村設郎，大森茂樹：RC造たれ壁・袖壁・腰壁付柱の㴊域および復元力 特性, 日本建築学会大会学術講演梗概集, 〈構造系>,pp.1451 1452, 1981

33）久徳琢栕,徳広育夫：片側袖壁付き柱の変形および而力に関する実験的研 究, 日本建築学会大会学術講演梗概集, C,pp.743 744, 1988

34）久徳琢穈,徳広育夫：鉄筋コンクリート造片側袖壁付き柱の耐力および変 形性状, 日本建築学会中国・九州支部研究報告, 1990, pp.321 324

35）大宮幸,松浦康人,香取慶一,林静雄：袖壁付き柱の破罗形式を考虑したせん 断終局強度に関する実験および考察, 日本建築学会構造系論文集, 第 553 号, $\mathrm{pp} .81 \sim 88,2002$ 年 3 月

36) 杉山智昭,中野克彦,松崎育弘：非構造壁を内蔵する鉄筋コンクリート造架 構の構造性能に関する実験的研究 一中柱が存在する架構の実験一，日本 建築学会学術講演梗概集, C-2,pp.538 pp.539, 2002.8 